\title{
DIE GEESTESVERTRAAGDE KIND EN DIE GEMEENSKAPSVERPLEEGKUNDIGE
}

\author{
Maria E. Norrish \\ Assistent-Streek Organiseerder van Verpleegdienste (Streek Suid-Transvaal), \\ Departement van Gesondheid, Welsyn en Pensioene
}

\section{SUMMARY}

As a member of the health team the community health nurse is in a key position to play an important role in the prevention of mental retardation and in the rehabilitation and support which is necessary. The work is of such a nature that she meets the mother and the child both in the formal setting of the clinic and in the more informal atmosphere of the home visit. She does therefore have an invaluable opportunity for observation and discussion at a personal level, which is not always possible for other members of the multidisciplinary team.

\section{INLEIDING}

Wolgens 'n verslag deur die Wêreldgesondheidsorganisasie "Child mental health and psychosocial development" (16:1977) word erge geestesvertraagheid by 4 uit elke 1000 kinders aangetref.

Met hierdie syfers tot ons beskikking, blyk dit 'n voldonge feit te wees dat elke gemeenskapsverpleegkundige binne die gemeenskap waar sy werksaam is, met geestesvertraagde kinders in aanraking sal kom.

Die verslag lui voorts: "Many problems are missed when only the parents are relied on for their identification and reporting. Public health nurses and trained primary health care workers can be instructed to obtain information systematically from parents, and it has been shown that such procedures can result in successful identification of virtually all children with serious mental retardation and language delay"' (27: 1977).

\section{WAT IS GEESTESVERTRAAGDHEID}

Die begrip geestesvertraagdheid impliseer 'n groep toestande waar die individu se intellektuele vermoëns onder die normale is. Hierdie subnormale intellektuele funksionering gaan noodwendig gepaard met ander probleme soos gebrekkige sosiale aanpassing en die onvermoë om enige vaardigheid teen die normale ontwikkelingstempo aan te leer.

\section{VEROORSAKENDE FAKTORE VAN GEESTES-} VERTRAAGDHEID

Die oorsake van geestesvertraagdheid kan in twee breè kategorieë ingedeel word, naamlik genetiese faktore en breinbeskadiging.

\subsection{Genetiese faktore}

Reeds by bevrugting word die indiwidu se erfmasse vasgelê. Dit is dan ook gedurende hierdie fase waar abnormale genetiese toestande kan ontstaan, byvoorbeeld Tay Sachs se siekte, wat resessief oorerflik is, of Mongolisme as gevolg van chromosoomafwykings.

\subsection{Beskadiging van die brein}

Daar is talle oorsake van breinbeskadiging, wat gedurende swangerskap, tydens geboorte of ná geboorte kan voorkom.

- Gedurende die eerste drie maande van swangerskap kan infeksies, soos die bekende rubella virus of die toksoplasma breinskade by die foetus met geestesvertraagdheid as 'n nagevolg bewerkstellig.

- Tydens die geboorteproses kan beserings aan die brein of anoksie geestesvertraagdheid veroorsaak.

- Ná geboorte kan sekere infeksies, toksiese middels of breinbeserings óok tot permanente breinskade en geestesvertraagdheid lei.

\subsection{Sosiosielkundige faktore}

'n Ongunstige sosiosielkundige omgewing beïnvloed intellektuele ontwikkeling nadelig. Hierdie ongunstige faktore, byvoorbeeld gebrekkige intellektuele stimulering, gewoonlik as gevolg van psigiese verwaarlosing, veroorsaak isolasie van die kind. Die kind word derhalwe nie die geleentheid tot kognitiewe ont- 
wikkeling en sosialisering gebied nie. 'n Voorbeeld hiervan is die gevalle van Anna en Isabelle.

- Anna, 'n buite-egtelike kind is deur haar streng oupa in 'n kamer geïsoleer, waar sy slegs genoegsame versorging vir haar voortbestaan ontvang het.

Nadat sy op ses-jarige ouderdom ontdek is, was haar fisiese toestand uiters swak en kon sy nie loop of praat of self eet nie. Sy het die indruk van doofheid en moontlike blindheid geskep. $\mathrm{Na} 4 \frac{1}{2}$ jaar se volgehoue aandag het Anna die vermoëns van 'n 2 - 3 jarige kind ontwikkel.

- Isabelle, ook 'n buite-egtelike kind, het $6^{1 / 2}$ jaar saam met haar doofstom moeder in 'n donker kamer in afsondering gelewe. Haar enigste kommunikasie met die moeder was deur middel van wedersydse gebare. Toe sy ontdek is, was haar gedragspatrone gelykstaande aan die van 'n sesmaande-oue baba. As gevolg van wanvoeding het sy aan Ragitis gely sowel as aan doofheid en geestesvertraagdheid (Biesanz en Biesanz 16 : 1973).

Doofheid kan ook 'n oorsaak van geestesvertraagdheid wees, omrede hierdie kinders uiters beperkte kommunikasie met hulle omgewing kan bewerkstellig.

\section{DIE ROL VAN DIE GEMEENSKAPSVER- PLEEGKUNDIGE}

As lid van die gesondheidspan is die gemeenskapsverpleegkundige in 'n besondere gunstige posisie om 'n belangrike voorkomende, rehabilitatiewe en ondersteunende rol te vervul. Uit die aard van haar werk in die gemeenskap ontmoet sy die moeder en die kind onder sowel die meer formele kliniek-situasie as die informele ontspanne tuisomstandighede. Die tuisbesoeke skep geleenthede vir waarneming en bespreking op 'n persoonlike basis, wat nie altyd in the formele klinieksituasie moontlik is nie.

\subsection{Voorkomende Rol}

\section{- Voorgeboortesorg}

As daar na die oorsake van geestesvertraagdheid gekyk word, is dit duidelik dat die gemeenskapsverpleegkundige kan intree om die toestand te voorkom, byvoorbeeld, aanmoediging van vroue om van voorgeboortesorgdienste gebruik te maak om sodoende die veilige verlossing van die baba te verseker en ook toestande van kernikterus te vermy.

\section{- Genetiese Afwykings}

Genetiese afwykings kan voorkom word deur vrouens wat as hoërisikogevalle beskou word betyds vir die nodige genetiese ondersoeke en raadgewing te verwys.
Omrede die gemeenskapsverpleegkundige die gesinne in haar gebied ken, is sy dikwels van afwykings van genetiese oorsprong by familielede bewus. Met hierdie kennis kan sy die betrokke vroue vóór swangerskap vir raadgewing verwys. 'n Kind wat met 'n geestesgebrek gebore is, word soms eerste deur die gemeenskapsverpleegkundige in die gemeenskap ontdek, indien die gebrek nie reeds by geboorte geïdentifiseer is nie. Dit is om hierdie rede dat die eerste tuis besoek ná ontslag van die pasgeborene uit die hospitaal só belangrik is. Die moeder is dikwels besorgd oor sommige aspekte van haar baba se vordering, maar het nog nie die vrymoedigheid of die geleentheid gehad om haar vrees hieroor uit te spreek nie. In haar tuisomgewing, sal sy die gemeenskapsverpleegkundige in haar vertroue neem. Hierdie waarneming van die moeder kan heelwaarskynlik die eerste indikasie van 'n afwyking wees. Die gemeenskapsverpleegkundige is dan in staat om die nodige advies te gee en verwysing te doen, om sodoende 'n herhaling van die genetiese afwyking te voorkom.

\section{- Rubella in swangerskap}

Immuniseringsdienste vir jong meisies teen rubella word deur sommige plaaslike owerhede aangebied. Tydens haar gesondheidsvoorligtingsprogramme by skole sowel as by ander groepe word die gemeenskap deur die gemeenskapsverpleegkundige teen die gevare van rubella gedurende die eerste trimester van swangerskap gewaarsku, sodat die nodige stappe daarteen geneem kan word.

\section{- Ensefalitis en meningitis}

Die gemeenskapsverpleegkundige poog deurgaans om alle kinders in haar gebied ten volle teen voorkomende aansteeklike siektes te laat immuniseer. Hierdeur word die gevaar van ensefalitis, as 'n komplikasie van masels, of tuberkulose-meningitis voorkom.

\section{- Breinbeserings}

Ongelukke, soos die omry van 'n kind terwyl 'n ouer met ' $n$ motor agteruit ry of wanneer 'n kind 'n toksiese middel inneem, kan die tragedie van permanente breinbeskadiging by ' $n$ gesonde normale kind veroorsaak. Deur volgehoue voorligting aan ouers by klinieke en tydens tuisbesoeke, maak die gemeenskapsverpleegkundige die ouers van gevare in en om die huis bewus.

\section{- Psigososiale ontwikkeling}

'n Gesonde ouer-kind-verhouding word deur die gemeenskapsverpleegkundige deur middel van groepbesprekings by klinieke en advies gedurende tuisbesoeke bewerkstellig. Waar daar 
'n gebrekkige band van liefde tussen die moeder en die kind heers, of daar tekens van verwerping van die kind deur een of beide ouers is, is daar die vóórdeel dat die gemeenskapsverpleegkundige hierdie probleme vroegtydig kan waarneem en die nodige stappe kan doen. Hoewel ernstige gevalle van kinderfoltering soms deur ouers verberg word, word die probleem gewoonlik vertroulik deur die bure onder die gemeenskapsverpleegkundige se aandag gebring sodat ingryping kan geskied.

\subsection{Vroeë Herkenning}

Vanweë haar kennis en ondervinding is die gemeenskapsverpleegkundige ingestel op die normale ontwikkeling van die indiwidu. Deur middel van gesonde-baba-klinieke sien sy babas en jong kinders met gereelde tussenposes waar die normale ontwikkelingsmylpale waargeneem en geëvalueer word. Afwykings van die verwagte normale word hierdeur vroeg herken en betyds vir verdere ondersoeke en diagnose verwys.

Tuisbesoeke bied geleenthede vir waarneming van 'n jong kind onder meer ontspanne omstandighede, en dit is juis gedurende die tuisbesoek dat 'n moeder haar kommer oor die vordering van haar kind uitspreek. Dit is altyd noodsaaklik om kennis te neem van enige vermoedens van die moeder oor haar kind se swak vordering. Die moeder is oor die algemeen korrek hieroor omdat sy haar kind daagliks versorg. Sy kan byvoorbeeld sê dat die baba nie soos sy broers of susters sy kop op 'n sekere ouderdom kan oplig nie; dat daar voedingsprobleme is en so meer.

Die noodsaaklikheid en belangrikheid van vroeë herkenning en diagnose van 'n geestesgebrek kan nie oorbeklemtoon word nie. Hoe vroeër terapie 'n aanvang kan neem, hoe meer sal die kind daarby kan baat.

\subsection{Hulp en bystand aan die Gesin}

Met die bewuswording van die ouers dat die jong kind ' $n$ geestesgebrek het, is hierdie besef vir die ouers en die gesin in sy geheel 'n geweldige skok. Hierdie skokreaksie word gekenmerk deur protes, wanhoop, aggressie, skuldgevoelens en dikwels ook godsdienstige konflik.

Die hoofrol van die gemeenskpsverpleegkundige is om die ouers te help om hulle eie gevoelens te verwerk, om hulle kind se toestand te begryp en hoe om hom te hanteer.

Weens die hewige emosionele reaksie van ouers is dit dikwels nodig om ander dissiplines, byvoorbeeld sielkundiges, maatskaplike werkers en kerklike instansies te betrek. Soms, as gevolg van die aggressiwiteit en skuldgevoelens, blameer die ouers mekaar vir die kind se afwyking. Dit is ook belangrik om die dienste van 'n huweliksvoorligter betyds te bekom.

Omdat die gemeenskapsverpleegkundige die skakeling tussen die spanlede en die gesin by die huis is, moet sy met die ander dissiplines skakel, sodat sy in staat is om die instruksies of advies wat deur hulle aan die moeder gegee is, te versterk wanneer tuisbesoeke gedoen word.

Dit is byvoorbeeld belangrik dat enige oefeninge wat deur die fisioterapeut of arbeidsterapeut voorgeskryf is, by die huis volgehou word. Omdat ouers die vertraagde kind bejammer of skuldgevoelens het, is hulle geneig om alles vir die kind te wil doen. Sodoende belemmer hulle spierontwikkeling en die kind leer nie primitiewe motoriese spierreflekse af nie. Die gemeenskapsverpleegkundige moet op hoogte bly van die oefeningsprogram sodat sy indien nodig adviserend kan optree.

Probleme met die inneem van voedsel is dikwels die eerste teken van 'n breinbeskadigde baba. Voedingstye ontwikkel in 'n emosionele uitputtende ondervinding vir die moeder en 'n fisiese uitputtende ondervinding vir die kind. Die suigen slukreflekse is gewoonlik swak, wat voedingstye noodwendig verleng. Daar is ' $n$ neiging om die byvoeging van vaste kosse uit te skakel omdat dit vir die moeder minder veeleisend is. Die moeder moet geleer word dat die vertraagde kind die geleentheid gegun moet word om verskeie teksture en geure kosse te ervaar tot voordeel van verdere ontwikkeling, byvoorbeeld koubewegings, en vir die kind se algehele gesondheid. Daar is spesiale aangepaste voedingstegnieke wat gebruik kan word om die vertraagde kind te voer. Die gemeenskapsverpleegkundige sal hierdie tegnieke aan die moeder verduidelik en demonstreer gedurende voedingstye by die huis.

Verskeie groepe het in die gemeenskap tot stand gekom as gevolg van persone wat met 'n gemeenskaplike probleem te kampe het. Sodoende bestaan daar groepe vir ouers van vertraagde kinders. Deur lede van so 'n groep te word, ontmoet die ouers ander met dieselfde probleem en word hulle onder die leiding van 'n professionele persoon gehelp om gemeenskaplike probleme soos opvoeding, sosiale en emosionele ervaringe te deel.

Die kwessie van plasing van die vertraagde kind in 'n inrigting, sal heelwaarskynlik ter sprake kom. Die gemeenskapsverpleegkundige moet te alle tye onpartydig en objektief hierteenoor op- 
tree. Sy is deeglik bewus van die voor- en nadele van inrigting- en tuissorg en sal hierdie feite aan die ouers oordra. Die gemeenskapsverpleegkundige is ook bewus van die huislike omstandighede van die gesin, byvoorbeeld of albei ouers werk, en wat verskeie inrigtings kan aanbied, byvoorbeeld dagsentra, vervoer, en so meer.

Die gemeenskapsverpleegkundige kan afsprake vir ouers met die verskillende inrigtings reël om sodoende die ouers met die besluit te help. Daar is geen "korrekte" of "ideale" besluit nie, maar die finale besluit berus by die ouers.

Die ervaring van ander kinders in die gesin teenoor die geestesvertraagde kind, hang af van die ouers se benadering en houding teenoor die vertraagde kind. Daar bestaan die moontlikheid dat 'n oorbeskermende ouer aan die geestesvertraagde kind meer aandag ten koste van normale kinders in die gesin gee.

Adolessente mag die teenwoordigheid van 'n geestesvertraagde kind in hulle gesin as 'n stigma ervaar. Dit kan veroorsaak dat die adolessente hulle sosiale kontak met hul maats verbreek om sodoende te verhoed dat die maats by hulle besoek aflê.

\section{Slot:}

Die voorgangers van vandag se gemeenskapsverpleegkundiges was persone van wie geen verpleegondervinding vereis was nie. Daar was byvoorbeeld die vriendelike besoekers van Amerika en sanitêre inspekteurs of gesondheidsbesoekers van Engeland. Hierdie persone was destyds gemoeid met tuisbesoeke aan die mindergegoedes in die gemeenskap, waartydens hulle voorligting oor higiëne voorsien het.

Vandag se gemeenskapsverpleegkundige beweeg op alle sosio-ekonomiese vlakke van die gemeenskap. Haar verpleegagtergrond en opleiding is van só 'n gehalte dat sy in staat is om 'n wye spektrum van fisiese en psigiese toestande sowel as sosiopatologiese verskynsels te kan uitken. Sy dra deeglike kennis van beskikbare hulpbronne binne die gemeenskap waarna persone vir spesialiseerde hulp verwys kan word.

Die gemeenskapsverpleegkundige is in die gunstige posisie om die geestesvertraagde kind vroeg te identifiseer en die nodige raad, leiding en ondersteuning aan die gesin te verleen, om sodoende hierdie gesinsgesentreerde probleem tot die meeste voordeel van alle betrokkenes te hanteer.

\section{BRONNELYS}

BOEKE

1. Biesanz, M.H. en Biesanz, J. 1973: Introduction to Sociology New Jersey-Prentice Hall lnc.

2. Geldenhuys, B.P. en du Toit, S.I. 1975: Psigopatologie Pretoria : Academica.

3. Mussen, P. H. \& Conger, J.J. \& Kagan, J. 1974: Child Development and Personality (4e Uitgawe) New York : Harper \& Row.

4. Suinn, R.M. 1975: Fundamentals of Behaviour Pathology (2e uitgawe) New York Wiley.

\section{ARTIKELS}

1. Grover, V.M. Junie 1978: Developmental Programmes for Mentally Retarded PreSchoolers, Rehabilitasie in S.A., Volume 22 - No. 1

2. SAH.N, S.T. 1978: A new nursing perspective, on the family with a special - needs child, Nursing Forum Volume XVII No. 4

\section{ANDER}

1. The S.A. National Council for Mental Health (W.O. 72): Mental Retardation.

2. W.H.O. Technical Report Series 613 1977: Child mental health and psychosocial development. Geneva: W.H.O 